\title{
Halk Kütüphanelerinin Bölgesel Dağılım Trendi: Gini Kat Sayılarıyla 1995-2005 Dönemi için Uygulamalar
}

\author{
Trend of Inequalitive Spatial Distribution For Public \\ Library: Gini Coefficient Applications From 1995 to 2005 \\ in Turkey
}

\section{Murat ÇiFTÇi ${ }^{*}$ \\ Mustafa TEKIN ${ }^{* *}$}

Öz

Halk kütüphaneleri, eğitim aracı olması sebebiyle kalkınma iktisadının, sosyal politikanın ve demografinin kapsamı içerisinde yer almaktadır. Bu çalışmada Türkiye' deki halk kütüphanelerinin bölgesel dağılım eşitsizliği incelenmiştir. Eşitsizlik göstergesi olarak Gini katsayıları kullanılmıştır. Yapılan uygulamalar sonucunda 1995-2005 arasında, halk kütüphanelerinin bölgelerarası dağılım eşitsizliğinde iyileşmenin yaşandığı tespit edilmiştir. Ancak bu iyileşmede il nüfusları göz ardı edilmektedir.

Anahtar sözcükler: Ekonomik gelişme, Politikalar, Demografi, İstatistik, Halk Kütüphaneleri

\section{Abstract}

In this study, inequalities in the spatial distribution of public libraries in Turkey was investigated. Gini-coefficients as inequality indicators were used. It was concluded that inequality in the spatial distribution of public libraries had substantially been decreased during the period

\footnotetext{
*Yardımcı Araştırmacı, İstanbul Üniversitesi BAP Birimi.

${ }^{*}$ Y.Doç.Dr.; Istanbul Üniversitesi iktisat Fakültesi Ekonometri Bölümü Beyazıt / İstanbul (muratciftci77@yahoo.com).
} 
of 1995 to 2005. It should however be noted that the analysis was realised without taking regard of the effect of relative populations of administrative units involved.

Keywords: Economic development, Policies, Demography, Statistics, Public libraries

\section{Giriş}

Tarih boyunca kütüphaneler bilimsel gelişmelerin merkezi olmuşlardır. Antik Yunan kütüphanelerinin yoğun beyin göçü çektikleri bilinmektedir (Tekin ve Çiftçi, 2007, s. 10). Sanayi devrimindeki teknolojik gelişmelerde kütüphanelerin işlevselliği azalmışsa da, 20. yüzyıl kütüphanelere tatbiki bilimde işlevselliği geri kazandırmıştır.

Geçmiş dönemlerin aksine günümüzde kütüphanelerin işlevleri sadece ileri düzey bilimsel araştırmalarda yararlanılan, dolayısıyla dar bir toplumsal katmanın rağbet gösterdiği alan özelliğinden önemli ölçüde sıyrılmıştır. Artık modern dünyada kütüphaneler, eğitimin her aşamasında başvurulan her yaştaki geniş halk kitlelerinin faydalanabildiği mekânlar konumundadır. Özetlemek gerekirse ilköğrenimden yetişkin öğrenimine, entelektüel amaçlı ziyaretlerden bilimsel çalışmalara kadar çok geniş bir kullanıcı tipolojisine sahip olup eğitim politikalarının merkezindeki araçlardan birisi konumuna erişmiştir.

Bilindiği gibi eğitim; kalkınmışlık göstergelerinden birisi olması ve bireysel üretkenliği arttırıcı etkisi sebebiyle kalkınma ekonomisinin, çalışma ekonomisi ve iktisadi demografinin; görev olarak devletin arz sağlayıcı ve destekleyici konumu sebebiyle de sosyal politikanın temel çalışma konuları arasında yer almaktadır. Kütüphaneler de, eğitimin her aşamasında okullar, kurslar, araştırma merkezleri gibi görev üstlenmesi sebebiyle bu bilim dallarının doğal olarak ilgi alanı içerisinde olacaktır.

Çalışma kapsamında yapılan uygulamalara esas olan kütüphanelerin üniversite, araştırma merkezleri gibi ihtisas kütüphanelerinden oluşmayıp; halk kütüphaneleri olması ise, kullanıcı tipolojisinin çok daha geniş bir yelpazeye yayılması sebebiyle ayrıca önemlidir.

Bu çalışmanın amacı da, hem toplam değerler hem de nüfusa göre ağırlıklandırmalarla ülkemizdeki halk kütüphanelerinin sayı, kitap hacmi ve kullanıcı sayı, kitap alıcısı miktarlarına göre iller arasındaki 
eşitsiz dağılımın boyutlarını tespit etmek ve zamana göre nasıl bir dönüşüm içerisinde olduğunu incelemektedir.

\section{Uygulama}

\section{Veriler}

Uygulamalara esas olan veriler, Türkiye İstatistik Kurumu (TUIKK) web sitesinin bölge istatistikleri bağlantısından elde edilmiştir.

\section{Yöntem}

Bölgeler arası eşitsizlik konusu bilim camiasında, daha çok gelir düzeyi ekseninde incelenmektedir. Bu çerçevede Gini, Robin Hood, Atkinson gibi endeksler tekli eşitsizlik endeksleri olarak ifade edilmektedir (Laporte, 2002, s. 1563).

Tekli eşitsizlik endeksleri içerisinde en popüler olanı Gini endeksidir. Eşitsizlik ölçümünde çok geniş bir uygulama alanı bulan Gini katsayısı ilk olarak 1912'de Gini tarafından türetilmiştir (Sen, 1973, ss. 29-30, 33-39). Gini katsayısı 0 ile 1 arasında değer alan bir katsayı olup; katsayının 1 olması durumunda tek bir gözlemin "bizde il”, dağılımı hesaplanan her ne ise "örneğin halk kütüphanesi, kitap, kullanıcı veya ödünç alınan kitap sayısı" tümünü tek başına aldığını; 0 olması ise bütün gözlemlerin dağılımı hesaplanan değerden eşit miktarda aldığını gösterir.

Gelir dağılımdaki eşitsizliğin ölçümünde ve bölgeler arasında karşılaştırma yapmada ekonomistler bu katsayıdan yararlanmaktadırlar (Pianegonda ve Iglesias, 2004, s. 197). Gini endeksinin cinsiyete dayalı eşitsizliklerin ölçülmesine yönelik çalışmalarda da erkek ve kadın olarak ayrı ayrı hesaplanarak karşılaştırıldığı görülmektedir (Mukhopadhaya, 2001, s. 559). Gelir dağılımı dışında servet, kira (Hwang, 2005) dağılım adaleti ölçümünde de yoğun olarak kullanılan endeksin kullanım alanı, sadece gelir ve türevleriyle de sınırlı kalmamaktadır. Enerji yoğunluğunun dağılımdaki eşitsizlik (Alcantara ve Duro, 2004), çevre konusunda emisyonun "hava, su, vs..." dağılımındaki eşitsizlik (Millimet ve Slottje, 2002) gibi çok çeşitli konular için de kullanılabilmektedir.

Gini katsayısının uluslar arası literatürdeki yaygın kullanımına karşılık ülkemizde henüz yeterli ilgiyi görmediğini savunmak 
mümkündür. Kuramsal bazda ve uygulamaların yorumlanması açısından gerek istatistik, gerekse de ekonomi alanında hemen herkesin bilgi sahibi olduğu katsayının hesaplanmasına yönelik uygulama içeren iki çalışma, ulusal literatür için ulaşılabilen Öztürk (2005)'ün makalesinden ve Gezici (2007)'nin tebliğinden ibarettir.

Gini katsayısının hesaplanmasında çeşitli metotlardan yararlanılmaktadır. Son yıllarda oldukça popüler olan yöntemde Gini katsayısı;

$$
G=\frac{2 k o \text { var } y a n s\left(Y, S_{y}\right)}{N \bar{Y}}
$$

formülüyle hesaplanmaktadır. Buna göre "G" Gini katsayısını; "Y" gözlem değerini, “ $\bar{Y}$ ” tüm gözlemlerin ortalama değerini, "N” gözlem sayısını ve " $S_{y}$ "en küçükten en büyüğe doğru olmak üzere gözlemlerin sıralarını sembolize etmektedir (Lerman ve Lerman, 1986, s. 325; Milanoviç, 1997, s. 45). Bu yöntemde Gini katsayısının en yüksek değeri 1'den küçük olmaktadır. Örneğin 80 gözlemli bir uygulamada sapma \% 1,25 düzeyinde olmaktadır. Bu sebeple katsayının standardize edilmesi gerekmektedir. Standardizasyonda LorenzMünznercoefficient yaklaşımı kullanılmaktadır (Stirböck, 2002, s. 6).

$$
\begin{aligned}
G_{s t} & =\left(\frac{2 k o \operatorname{var} y a n s\left(Y, S_{y}\right)}{N \bar{Y}}\right) \times\left(\frac{N}{N-1}\right) \Rightarrow \\
G_{s t} & =\left(\frac{2 k o \operatorname{var} y a n s\left(Y, S_{y}\right)}{(N-1) \times \bar{Y}}\right)
\end{aligned}
$$

Standardizasyon sonrasında Gini katsayıları [0,1] arasında değişmektedir.

\section{Uygulama Sonuçları}

Hesaplanan sekiz Gini grubu için 1995-2005 dönemini içeren toplam 88 Gini katsayısı "8x11" hesaplanmıştır. Hesaplamada değişken hakkında bilginin olduğu iller kullanılmış, bilgi olmayanlar hesaplama dışı bırakıımıştır. Ardından bir önceki yıla göre Gini katsayılarındaki 


\section{yüzdesel değişimler ve $1995=100$ endeksleri hesaplanmıştır. Toplu sonuçlar Tablo 1' de sunulmaktadır.}

Tablo 1. Uygulama Toplu Sonuç Tablosu

\begin{tabular}{|c|c|c|c|c|c|c|c|c|c|c|c|c|}
\hline & & 1995 & 1996 & 1997 & 1998 & 1999 & 2000 & 2001 & 2002 & 2003 & 2004 & 2005 \\
\hline \multirow{4}{*}{ 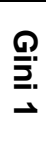 } & Katsayı & 0.401 & 0.400 & 0.393 & 0.386 & 0.383 & 0.387 & 0.386 & 0.378 & 0.384 & 0.378 & 0.365 \\
\hline & $\mathbf{N}$ & 79 & 80 & 80 & 80 & 80 & 81 & 81 & 81 & 81 & 81 & 81 \\
\hline & Değişim (\%) & & -0.3 & -1.8 & -1.8 & -0.8 & 1.0 & -0.3 & -2.1 & 1.6 & -1.6 & -3.5 \\
\hline & $1995=100$ & 100.0 & 99.7 & 98.0 & 96.2 & 95.4 & 96.4 & 96.2 & 94.2 & 95.7 & 94.2 & 90.9 \\
\hline \multirow{4}{*}{$\frac{Q}{\Sigma}$} & Katsayı & 0.475 & 0.472 & 0.464 & 0.461 & 0.458 & 0.461 & 0.438 & 0.433 & 0.429 & 0.430 & 0.428 \\
\hline & $\mathbf{N}$ & 79 & 80 & 80 & 80 & 80 & 81 & 81 & 81 & 81 & 81 & 81 \\
\hline & Değişim (\%) & & -0.7 & -1.7 & -0.7 & -0.7 & 0.6 & -4.8 & -1.2 & -0.9 & 0.2 & -0.5 \\
\hline & $1995=100$ & 100.0 & 99.3 & 97.6 & 97.0 & 96.4 & 97.0 & 92.3 & 91.2 & 90.4 & 90.6 & 90.2 \\
\hline \multirow{4}{*}{$\frac{\Omega}{\underline{\omega}}$} & Katsayı & 0.417 & 0.523 & 0.393 & 0.413 & 0.418 & 0.396 & 0.392 & 0.376 & 0.372 & 0.381 & 0.380 \\
\hline & $\mathbf{N}$ & 79 & 80 & 80 & 80 & 80 & 81 & 81 & 81 & 81 & 81 & 81 \\
\hline & Değişim (\%) & & 25.2 & -24.8 & 5.2 & 1.2 & -5.3 & -1.0 & -4.1 & -1.0 & 2.5 & -0.3 \\
\hline & $1995=100$ & 100.0 & 125.2 & 94.2 & 99.0 & 100.2 & 94.9 & 93.9 & 90.0 & 89.1 & 91.3 & 91.0 \\
\hline \multirow{4}{*}{$\frac{Q}{2}$} & Katsayı & 0.464 & 0.455 & 0.428 & 0.437 & 0.363 & 0.437 & 0.424 & 0.423 & 0.409 & 0.413 & 0.416 \\
\hline & $\mathbf{N}$ & 79 & 80 & 80 & 80 & 80 & 81 & 81 & 81 & 81 & 81 & 81 \\
\hline & Değişim (\%) & & -2.0 & -5.8 & 2.1 & -17.1 & 20.7 & -3.0 & -0.2 & -3.3 & 1.0 & 0.7 \\
\hline & $1995=100$ & 100.0 & 98.0 & 92.3 & 94.3 & 78.2 & 94.3 & 91.5 & 91.3 & 88.2 & 89.1 & 89.7 \\
\hline \multirow{4}{*}{$\frac{Q}{\mathrm{v}}$} & Katsayı & 0.339 & 0.343 & 0.342 & 0.339 & 0.348 & 0.328 & 0.334 & 0.350 & 0.347 & 0.352 & 0.372 \\
\hline & $\mathbf{N}$ & 79 & 80 & 80 & 80 & 80 & 81 & 81 & 81 & 81 & 81 & 81 \\
\hline & Değişim (\%) & & 1.0 & -0.4 & -0.9 & 2.7 & -5.6 & 1.8 & 4.9 & -1.0 & 1.7 & 5.6 \\
\hline & $1995=100$ & 100.0 & 101.0 & 100.6 & 99.7 & 102.4 & 96.7 & 98.4 & 103.2 & 102.1 & 103.8 & 109.6 \\
\hline \multirow{4}{*}{$\frac{\rho}{\Xi}$} & Katsayı & 0.322 & 0.330 & 0.330 & 0.334 & 0.340 & 0.340 & 0.352 & 0.357 & 0.359 & 0.363 & 0.362 \\
\hline & $\mathbf{N}$ & 79 & 80 & 80 & 80 & 80 & 81 & 81 & 81 & 81 & 81 & 81 \\
\hline & Değişim (\%) & & 2.6 & -0.1 & 1.3 & 1.8 & -0.1 & 3.4 & 1.5 & 0.6 & 1.2 & -0.2 \\
\hline & $1995=100$ & 100.0 & 102.6 & 102.5 & 103.9 & 105.7 & 105.6 & 109.2 & 110.8 & 111.5 & 112.8 & 112.6 \\
\hline \multirow{4}{*}{ 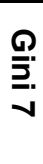 } & Katsayı & 0.323 & 0.417 & 0.343 & 0.354 & 0.376 & 0.352 & 0.345 & 0.338 & 0.297 & 0.328 & 0.327 \\
\hline & $\mathbf{N}$ & 79 & 80 & 80 & 80 & 79 & 80 & 81 & 81 & 79 & 78 & 81 \\
\hline & Değişim (\%) & & 29.0 & -17.7 & 3.2 & 6.3 & -6.5 & -2.0 & -2.0 & -12.2 & 10.5 & -0.3 \\
\hline & $1995=100$ & 100.0 & 129.0 & 106.2 & 109.6 & 116.5 & 108.9 & 106.7 & 104.6 & 91.8 & 101.5 & 101.2 \\
\hline \multirow{4}{*}{$\frac{\rho}{\Xi}$} & Katsayı & 0.392 & 0.391 & 0.406 & 0.387 & 0.376 & 0.383 & 0.384 & 0.397 & 0.384 & 0.391 & 0.401 \\
\hline & $\mathbf{N}$ & 79 & 79 & 80 & 80 & 79 & 80 & 81 & 80 & 80 & 78 & 81 \\
\hline & Değişim (\%) & & -0.3 & 3.9 & -4.8 & -2.7 & 1.8 & 0.3 & 3.3 & -3.5 & 1.8 & 2.8 \\
\hline & $1995=100$ & 100.0 & 99.7 & 103.6 & 98.7 & 96.0 & 97.7 & 98.1 & 101.4 & 97.8 & 99.6 & 102.4 \\
\hline \multicolumn{13}{|c|}{ 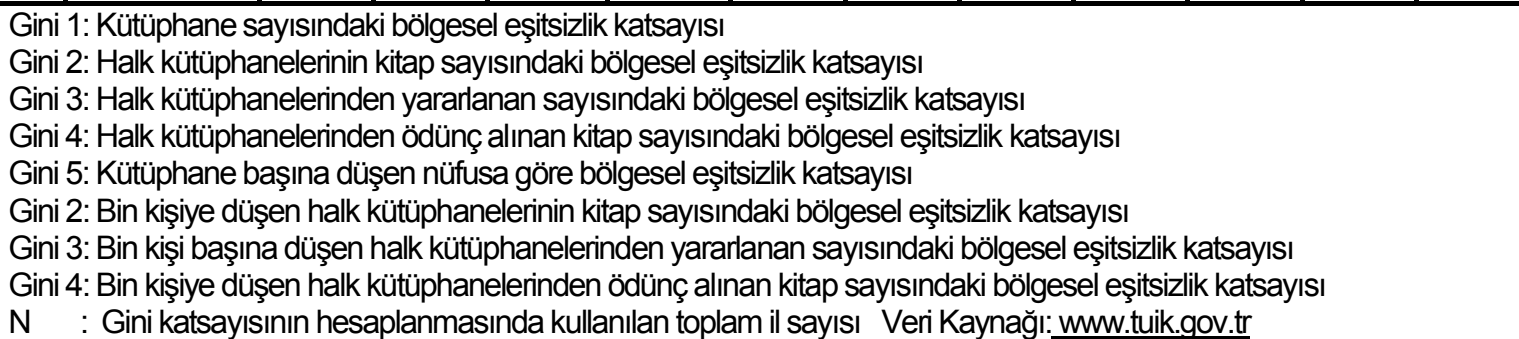 } \\
\hline
\end{tabular}

Konunun derinlemesine incelenerek yorumlanabilmesi için Tablo 1'deki Gini katsayılarının esas alındığı grafiklerden yararlanılmıştır. 


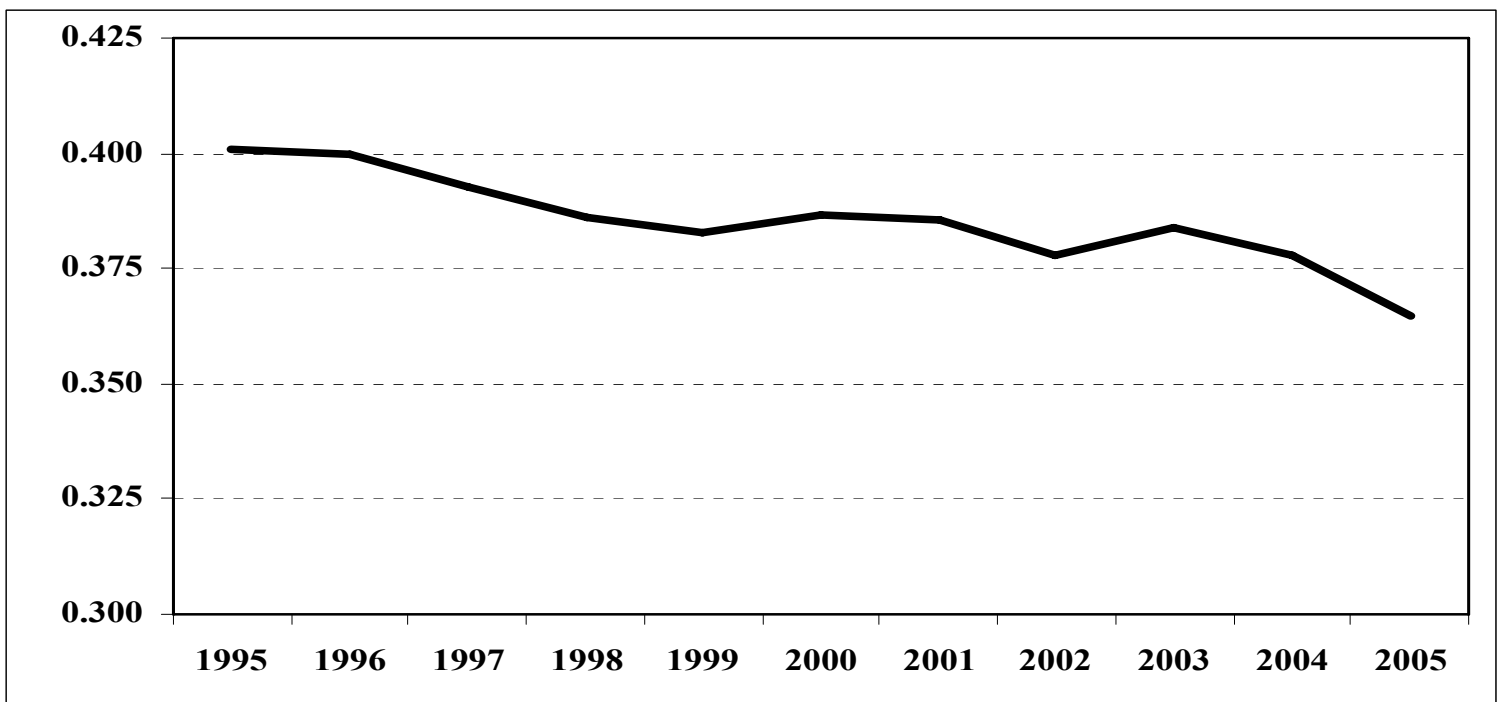

Grafik 1. Halk Kütüphanesi Sayısındaki Bölgesel Eşitsizliğin Zamansal Gelişimi (1995-2005)

Grafik 1'de görüldüğü gibi, 1995-2005 periyodunda geçen 11 yıllık süre içerisinde halk kütüphanelerinin iller arasındaki sayısal dağılımlarında yaşanan eşitsizliğin istikrarlı şekilde azaldığı sonucuyla karşılaşılmaktadır. Bu azalışın keskin olmamakla birlikte istikrarlı olması son derece önemlidir. Çünkü bu durum, idarenin sosyal politika görev kapsamı içerisinde kütüphanesi olmayan ya da sayıca son derece az olan illere yönelik olarak yeni kütüphaneler kurduğunu desteklemektedir.

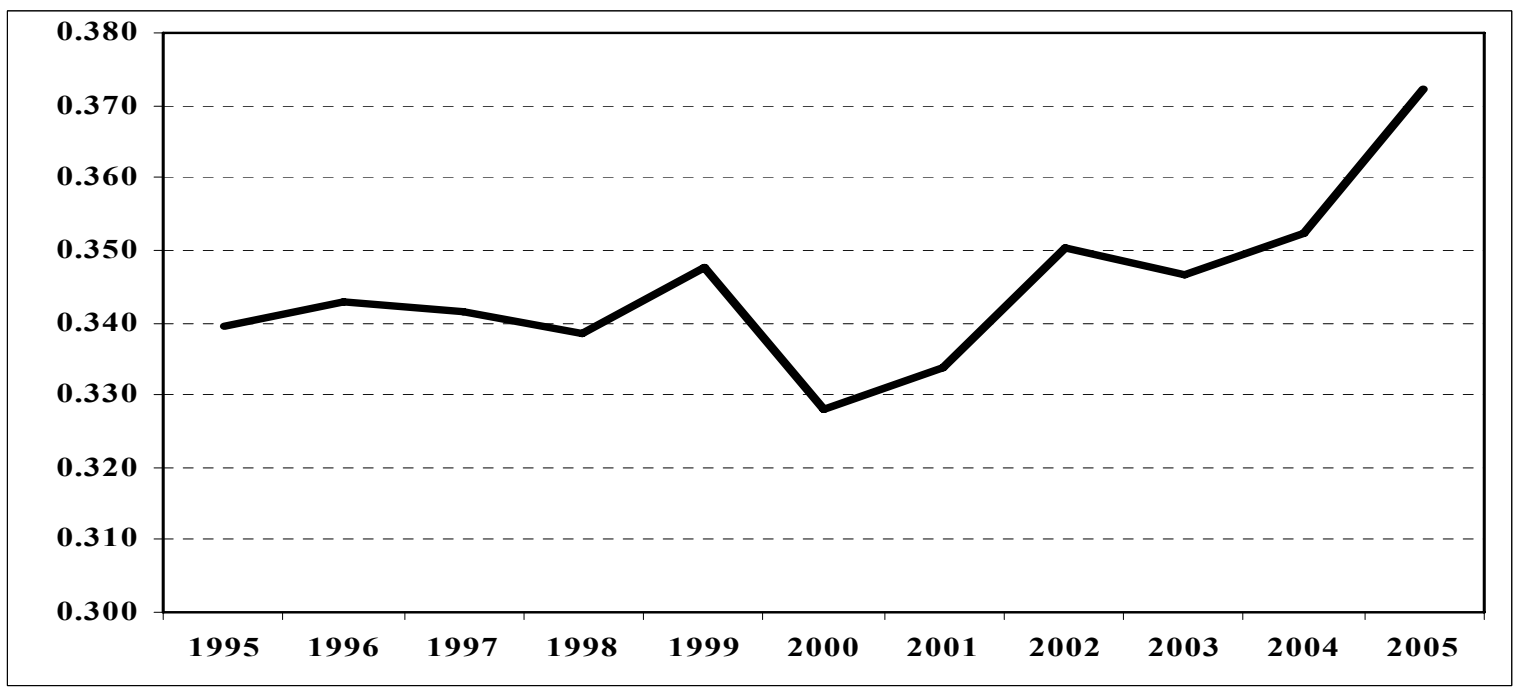

Grafik 2. Halk Kütüphanesi Başına Düşen Nüfus Sayısındaki Bölgesel Eşitsizliğin Zamansal Gelişimi (1995-2005) 
Kütüphanelerin iller arası dağılımında yaşanan eşitlikçi gelişime karşılık, il nüfusları dikkate alındığında halk kütüphanesi başına düşen nüfus miktarına göre son 11 yıllık dönemde çok ciddi bir bozulmanın yaşandığı görülmektedir. Bu bozulma hareketinin anlamı, idarenin yeni kütüphaneler kurmada, kurulacak yerdeki nüfus miktarını göz ardı eden bir yaklaşım içerisinde olduğudur. Diğer bir deyişle idare yeni kütüphaneleri açarken, nüfusu göz ardı etmekte ve mevcut olan iller arasındaki nüfusa göre eşitsizliğin daha da artmasına yol açmaktadır.

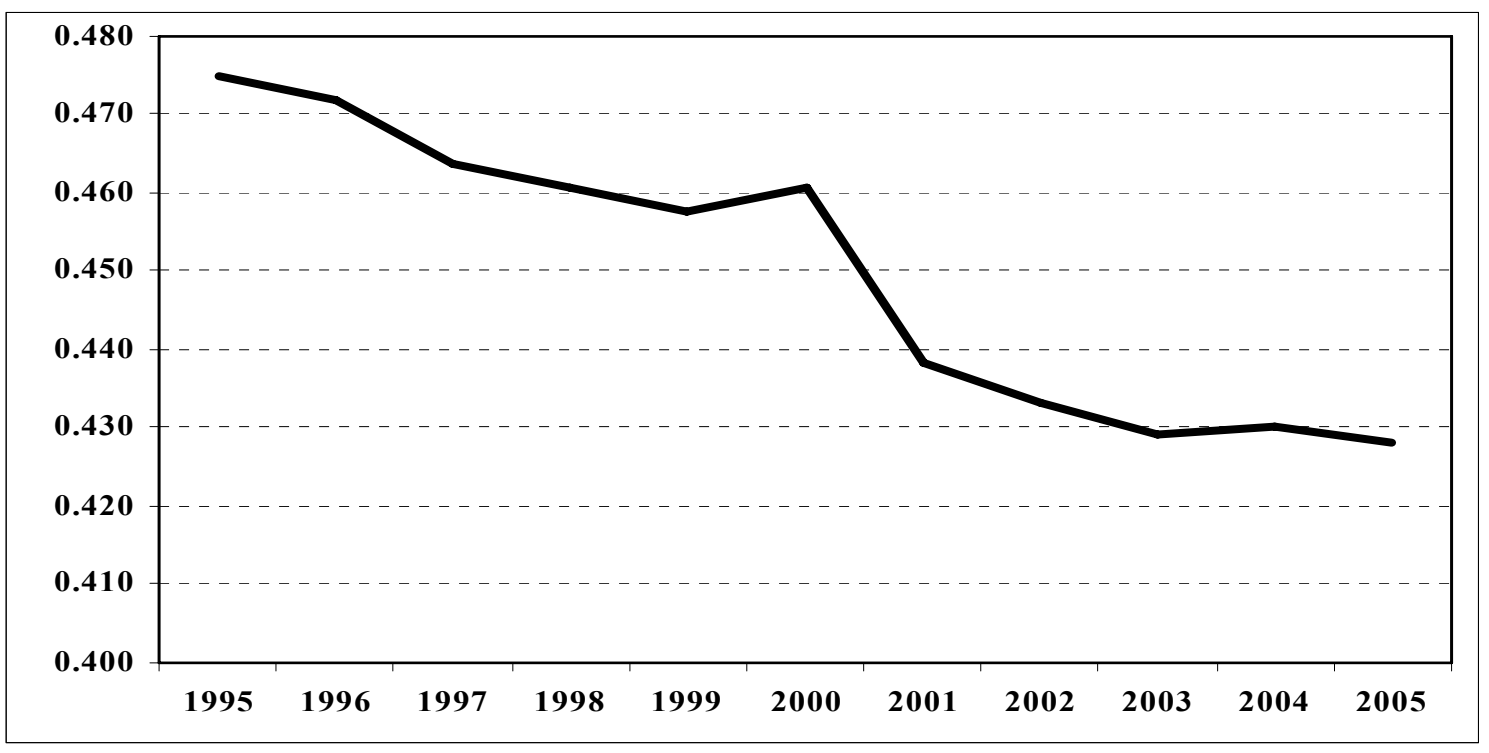

Grafik 3. Halk Kütüphanelerinin Kitap Sayısındaki Bölgesel Eşitsizliğin Zamansal Gelişimi (1995-2005)

Grafik 3'de 1995-2005 periyodunda geçen 11 yıllık süre içerisinde halk kütüphanelerindeki kitap miktarının iller arasındaki sayısal dağılımlarında yaşanan eşitsizliğin zamansal gelişimi sunulmaktadır. Kitap sayısındaki bölgesel eşitsizlikte, 2000 yılındaki geçici bozulma dışında kütüphane sayısından çok daha hızı bir azalışın yaşanmış olduğu görülmektedir. Dolayısıyla sadece kütüphanesi olmayan ya da az sayıda olan illere yeni kütüphane kurulmasıyla sınırlı kalınmadığı; binaların içeriğinin de zenginleştirildiği ve bu çerçevede iller arasındaki halk kütüphaneleri kitap hacmi dağılımları arasında ciddi bir eşitlikçi düzelmenin gerçekleştiği sonucuyla karşılaşılmaktadır. 


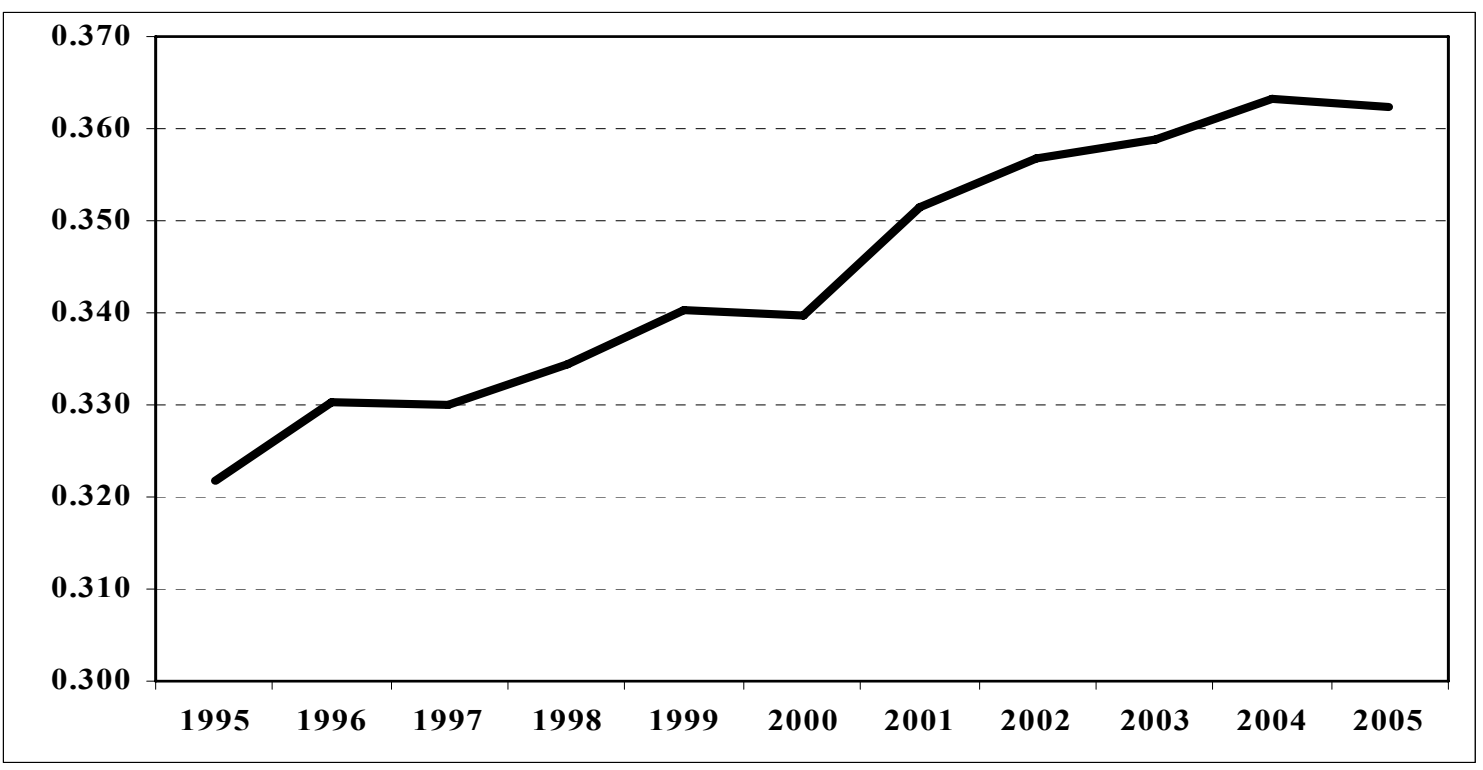

Grafik 4. Bin Kişi Başına Düşen Halk Kütüphanelerinin Kitap Sayısındaki Bölgesel Eşitsizliğin Zamansal Gelişimi (1995-2005)

Kütüphanelerdeki kitap sayılarında iller arası dağılımda yaşanan eşitlikçi gelişime karşılık il nüfusları dikkate alındığında, son 11 yıllık dönemde, bin kişi başına düşen halk kütüphanelerindeki kitap sayısında halk kütüphaneleri başına düşen nüfusa göre çok daha sert bir bozulmanın yaşandığı görülmektedir. Bu bozulma hareketinin anlamı, idarenin yeni kurulan kütüphanelere kitap sağlamada, illerin nüfus miktarını göz ardı eden bir yaklaşım içerisinde olduğudur. Diğer bir deyişle yeni kitap arzı yaratılırken, nüfus göz ardı edilmekte mevcut iller arası eşitsizliğin daha da artmasına yol açılmaktadır.

Grafik 5'de görüleceği gibi, halk kütüphanelerinden yararlananların sayısı açısından bölgesel eşitsizliğin 1995-2005 periyodundaki gelişimine bakıldığında oldukça gelgitli yüksek bir zamansal hareketin varlığıyla karşılaşılmaktadır. Bu gelgit özellikle 1995-1997 yılları arasında zirve yapmış, 1999 yılından sonra 2003 yılına kadar yavaş da olsa düzelmiş, bu tarihten sonra ise sınırlı da olsa kısmen bozulma eğilimine girmiştir. Özetlemek gerekirse, kullanıcı sayısının bölgesel dağılım eşitsizliğinde istikrarsız bir hareketin olduğu sonucuna varılabilir. Buradan hareketle halk kütüphanelerinin geniş kitleler için çekim merkezi olma vasıflarını artırmada yetersiz kaldığı savunulabilir. 


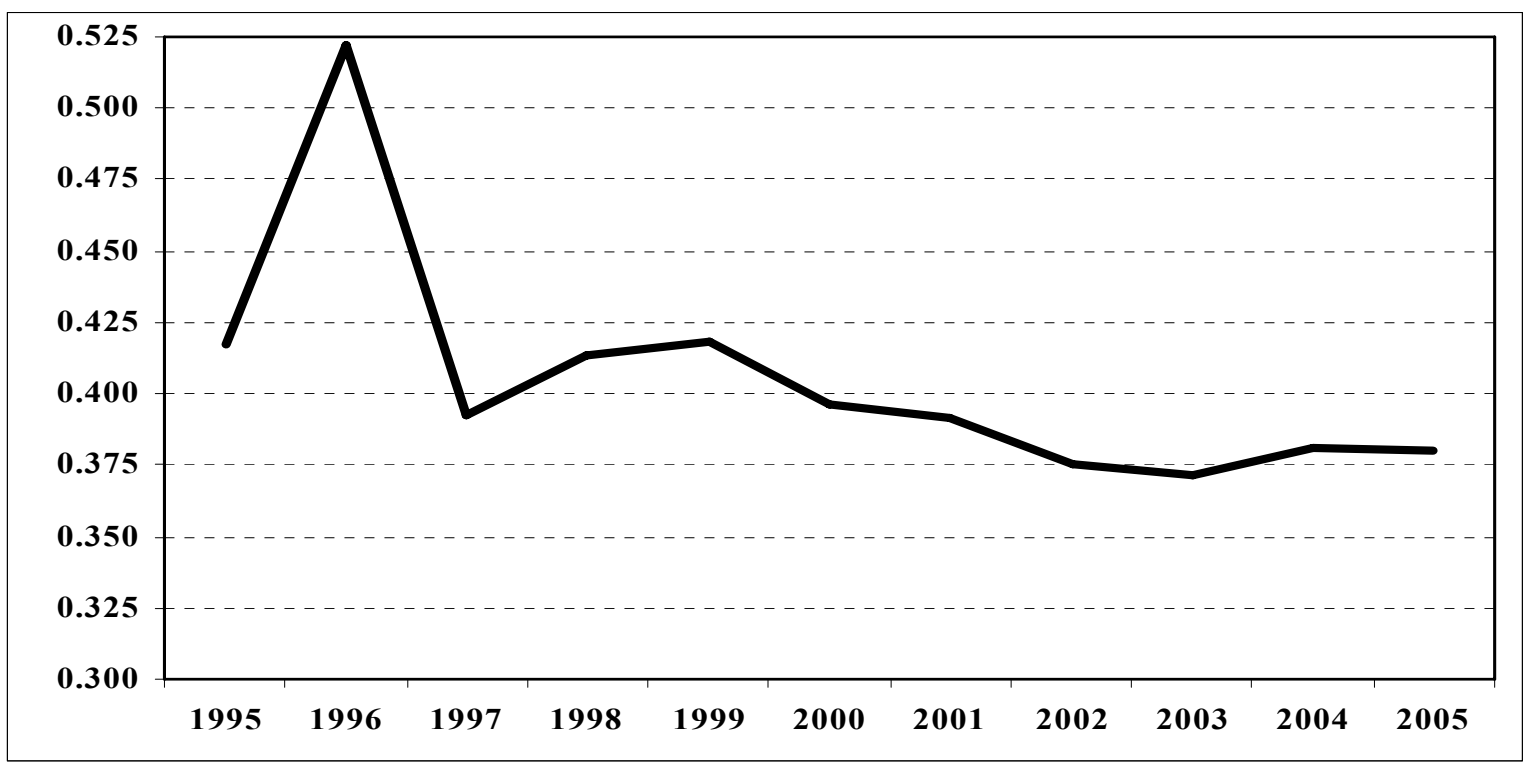

Grafik 5. Halk Kütüphanelerinden Yararlanan Sayısındaki Bölgesel Eşitsizliğin Zamansal Gelişimi (1995-2005)

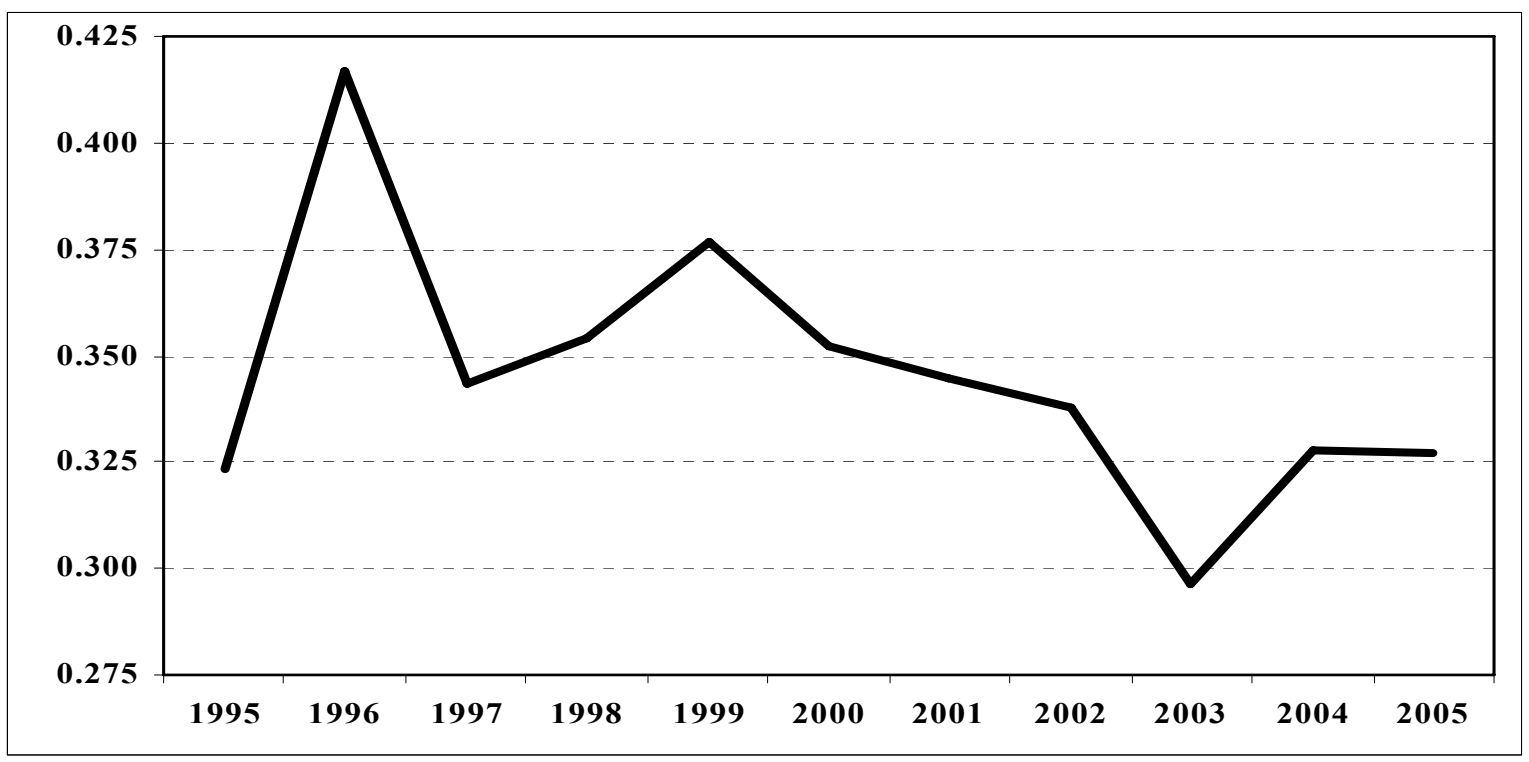

Grafik 6. Bin Kişiye Düşen Halk Kütüphanelerinden Yararlanan Kullanıcı Sayısındaki Bölgesel Eşitsizliğin Zamansal Gelişimi (1995-2005)

Halk kütüphanelerinden yararlananların il nüfuslarına göre yeniden yapılandırıması sonrasında yapılan uygulamalarda, iller arası talepte ciddi bir iyileşmenin yaşanmadığı görülmüştür. Diğer bir deyişle idarenin yeni kütüphaneler kurması ve kitap hacmini artırması, 
bölgeler arasında uyumun olmasını sağlayacak ölçüde kitleleri kütüphanelere çekme yönünde etki sağlamamıştır.

Grafik 7 incelendiğinde, halk kütüphanelerinden ödünç alınan kitap sayısı açısından bölgesel eşitsizliğin, 1999'daki dip yapmasından sonra 2000 yllında yükselmiş olmakla birlikte, dip hareketi göz ardı edildiğinde, ödünç kitap sayısındaki bölgesel eşitsizlikte düşük hızlı ancak düzenli bir azalışın olduğu sonucuna varılabilir.

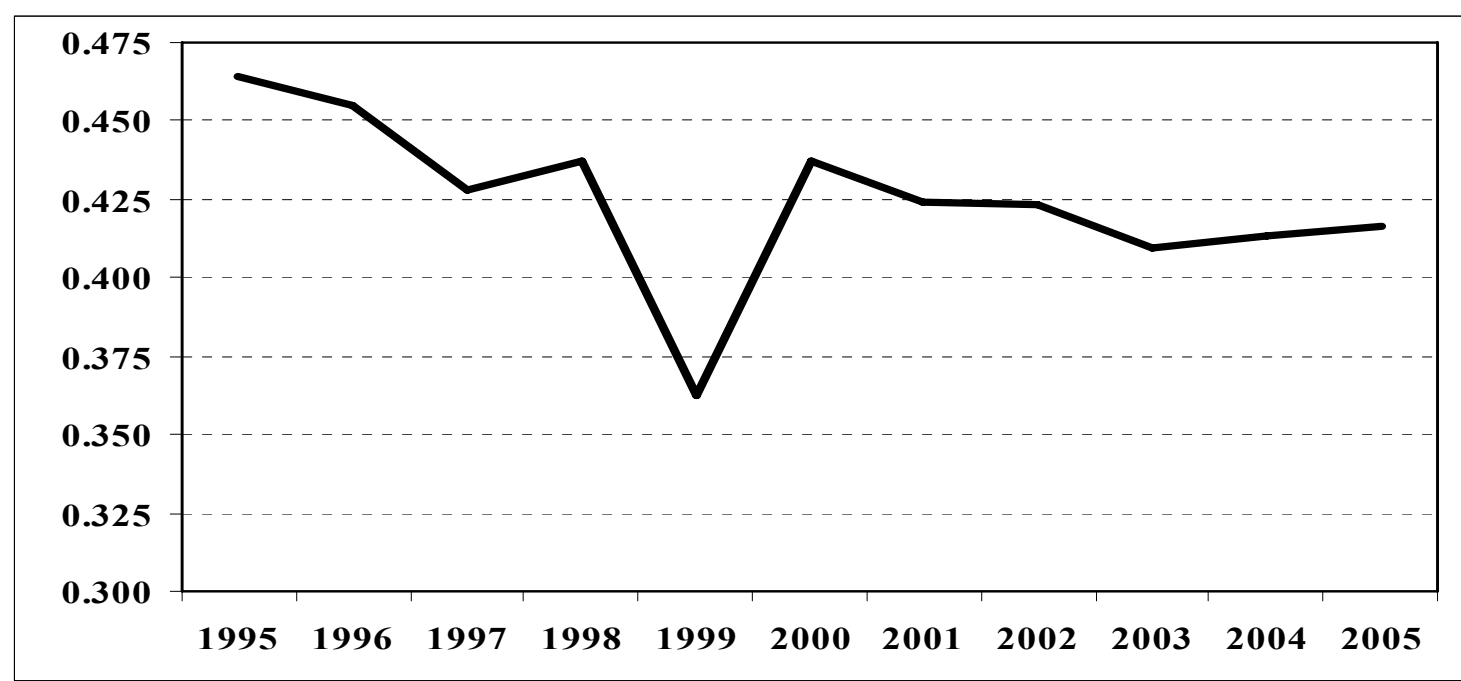

Grafik 7. Halk Kütüphanelerinden Ödünç Alınan Kitap Sayısındaki Bölgesel Eşitsizliğin Zamansal Gelişimi (1995-2005)

Grafik 8 incelendiğinde ise, halk kütüphanelerinden ödünç alınan kitap sayılarının il nüfuslarına göre yeniden yapılandırıması sonrasında yapılan uygulamalarda, iller arası talepte özellikle 1999'daki dip noktasından sonra bir bozulma eğiliminin yaşandığı görülmüştür. Hatırlanacağı üzere Grafik 5 ve Grafik 6'da istikrarsız bir yıllık hareket; Grafik 7'de ise çok düşük hızlı bir düzelme olmakla birlikte düzenli bir bozulma eğilimine de rastlanmamıştı. Grafik 8'de ise 1999'dan itibaren bir bozulma eğiliminin ipuçlarına ulaşılmaktadır. Bu durum il nüfusuna göre ödünç kitap alımının dengesizleştiği anlamını taşımaktadır. İki temel talep göstergesi olarak alınan kullanıcı ve ödünç kitap sayıları içinde talep için gösterge kabiliyeti daha yüksek olanı ödünç kitap sayısıdır. Çünkü bu gösterge, faal olarak kütüphanelerden yararlanılma düzeyini temsil eder. Hâlbuki kütüphaneye gelişler kimi zaman temel amacından sapabilir. Bir buluşma yeri olarak kullanımı ya da öğrencilerin gezi amaçlı toplu ziyaretleri 
gibi sebepler, gerçek faal kullanıcı sayısının olduğundan daha yüksek çıkmasına yol açabilir. Nitekim bu kütüphanelere girişlerde kısıtlama yoktur. Bu çerçevede ödünç alınan kitap sayısında bir bozulma eğiliminin ipuçlarının elde edilmesi, talep cephesinden olumsuz bir eşitsizlik yapısının oluştuğu hükmüne varılmasına imkân tanımaktadır.

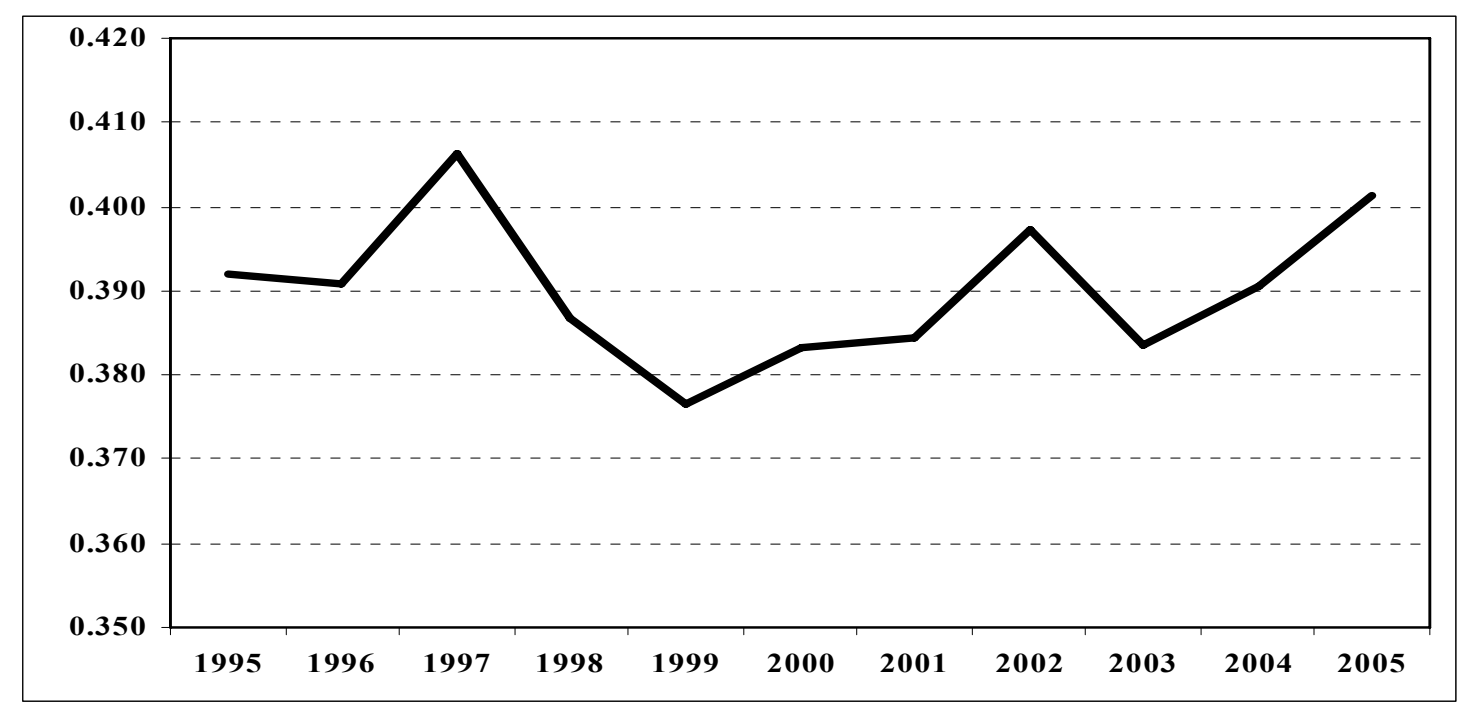

Grafik 8. Bin Kişiye Düşen Halk Kütüphanelerinden Ödünç Alınan Kitap Sayısındaki Bölgesel Eşitsizliğin Zamansal Gelişimi (1995-2005)

Bir sonraki aşama olarak Grafik 9 ve Grafik 10'da hizmet arzı (halk kütüphanesi ve kitap mevcudu sayıları) ve hizmet talebindeki (yararlanan ve ödünç alınan kitap sayıları) bölgesel dağılım eşitsizliğindeki bir önceki yıla göre yüzdesel değişimlerin gelişimleri incelenmiştir. Hesaplamada kullanılan eşitlik 4 numaralı denklemde sunulmaktadır.

$$
\operatorname{Deg}_{t, t-1}=\frac{\text { Gini }_{t}-\text { Gini }_{t-1}}{\text { Gini }_{t-1}} \times 100
$$




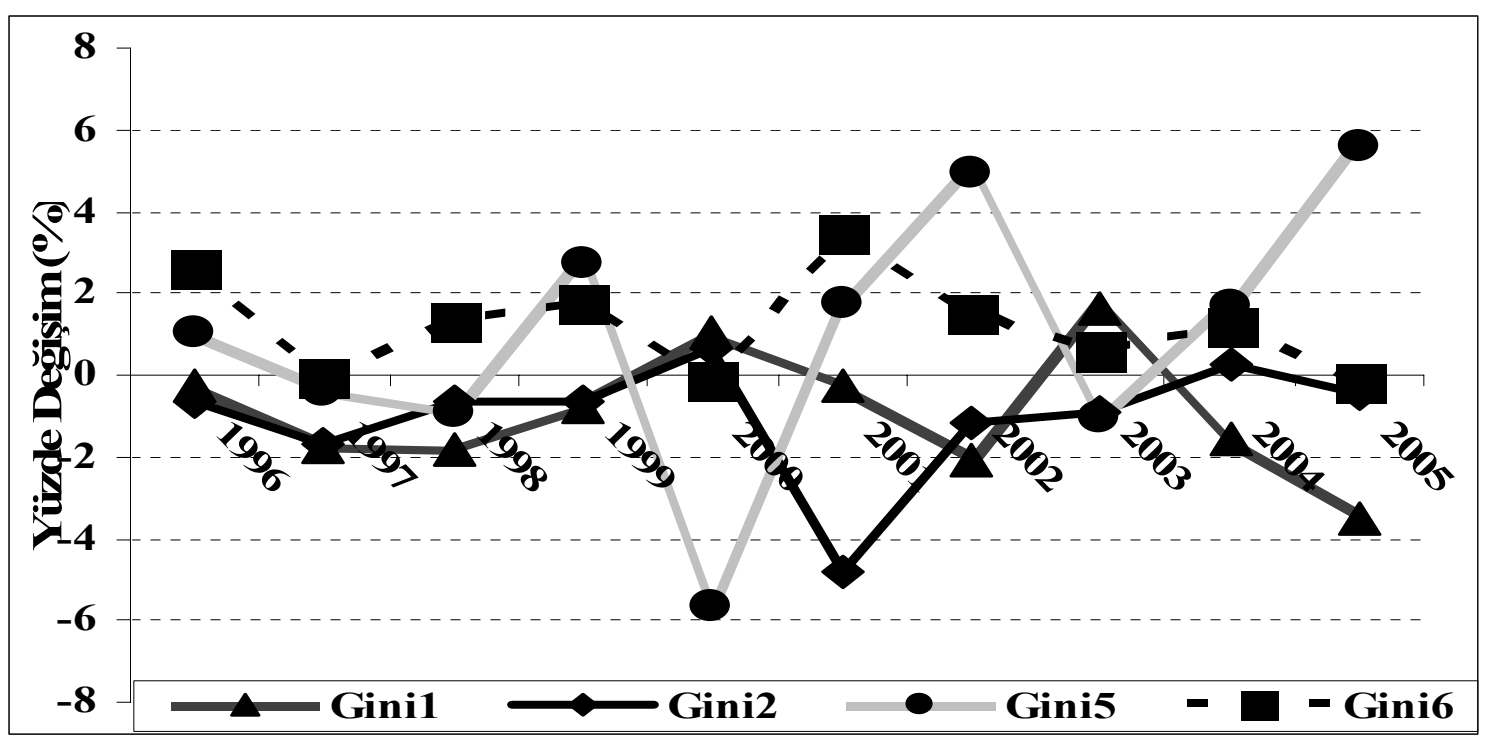

Grafik 9. Gini 1, 2, 5 ve 6 Katsayılarının Bir Önceki Yıla Göre Yüzdelik Değişimleri (1996-2005, \%)

Hizmet arzındaki yıllık oransal değişim hareketi Grafik 10'da görüleceği üzere yıllık değişimin \pm 6 bandında gerçekleşmektedir. Talebe göre oransal değişimin düşüklüğü dışındaki dikkat çekici gelişme ise, bölgesel dağılım eşitsizliğinde toplam sayılar ve nüfusa göre düzeltmeler arasında hem kütüphane sayısında "Gini 1 ve Gini 5" hem de kitap sayısında "Gini 2 ve Gini 6" birbirleriyle uyumlu olmayan yıllık değişimlerin mevcut olduğudur. Hâlbuki nüfusa göre düzeltme yapılmayan Gini 1 ve Gini 2 değişimlerinde sadece iki yıl bozulmanın olmasına karşılık nüfusa göre düzeltmelerde hem Gini 5 hem de Gini 6'da birkaç istisnai yıl dışında bozulma eğiliminin yaşanması birbirleriyle uyumludur. Bu sonuçlardan hareketle 11 yıllık dönem bütünü için kamu erkinin, kütüphanelerin bölgesel dağılım eşitsizliğini düşürecek etkin ve istikrarlı bir sosyal politika takip etmeyi amaçladığını, ancak nüfusla uyumlu olan eşitlikçi bir dönüşümün başarılamadığını savunmak yanlış olmayacaktır. 


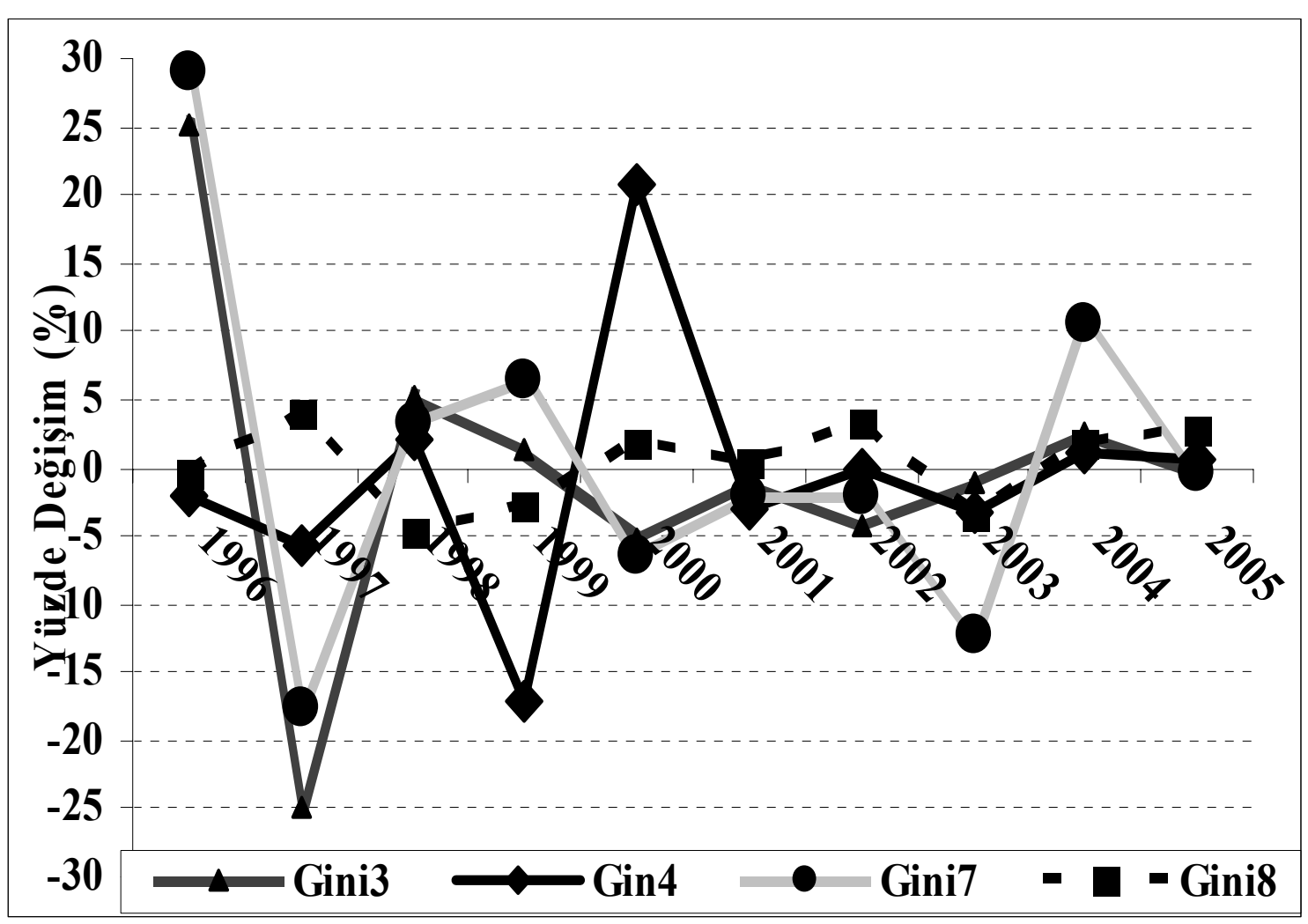

Grafik 10. Gini 3, 4, 7 ve 8 Katsayılarının Bir Önceki Yıla Göre Yüzdelik Değişimleri (1996-2005, \%)

Hizmet talebindeki yıllık oransal değişim hareketi cephesinden konu ele alındığında, Grafik 10'da görüleceği üzere, yıllık değişim \pm 30 bandında olup bu hareketlilik arza göre çok yüksek inişçıkışların olduğu anlamını taşımaktadır. Dikkat çeken diğer bir konuysa, bölgesel dağılım eşitsizliğinde gerek kullanıcı sayısı "Gini 3 ve Gini 7" gerekse ödünç alınan kitap sayısı "Gini 4 ve Gini 8" açısından; arzın bölgesel dağılım eşitsizliğindeki gibi birbiriyle çok fazla uyumlu olmayan bir yapının mevcut olduğudur.

Bir sonraki aşama olarak Grafik 11, Grafik 12, Grafik 13 ve Grafik 14'te hizmet arzı (halk kütüphanesi ve kitap mevcudu sayıları) ve hizmet talebindeki (yararlanan ve ödünç alınan kitap sayıları) bölgesel dağılım eşitsizliğinin, 1995 yılı düzeyine göre "1995=100 endeksi" gelişimleri incelenmiştir. Hesaplamada kullanılan eşitlik 5 numaralı denklemde sunulmaktadır. 
Endeks $_{\text {gin }_{1995-100}}=\left(\frac{\text { Gini }_{1995}+\left(\text { Gini }_{t}-\text { Gini }_{1995}\right)}{\text { Gini }_{1995}}\right) \times 100=\left(\frac{\text { Gini }_{t}}{\text { Gini }_{1995}}\right) \times 100$

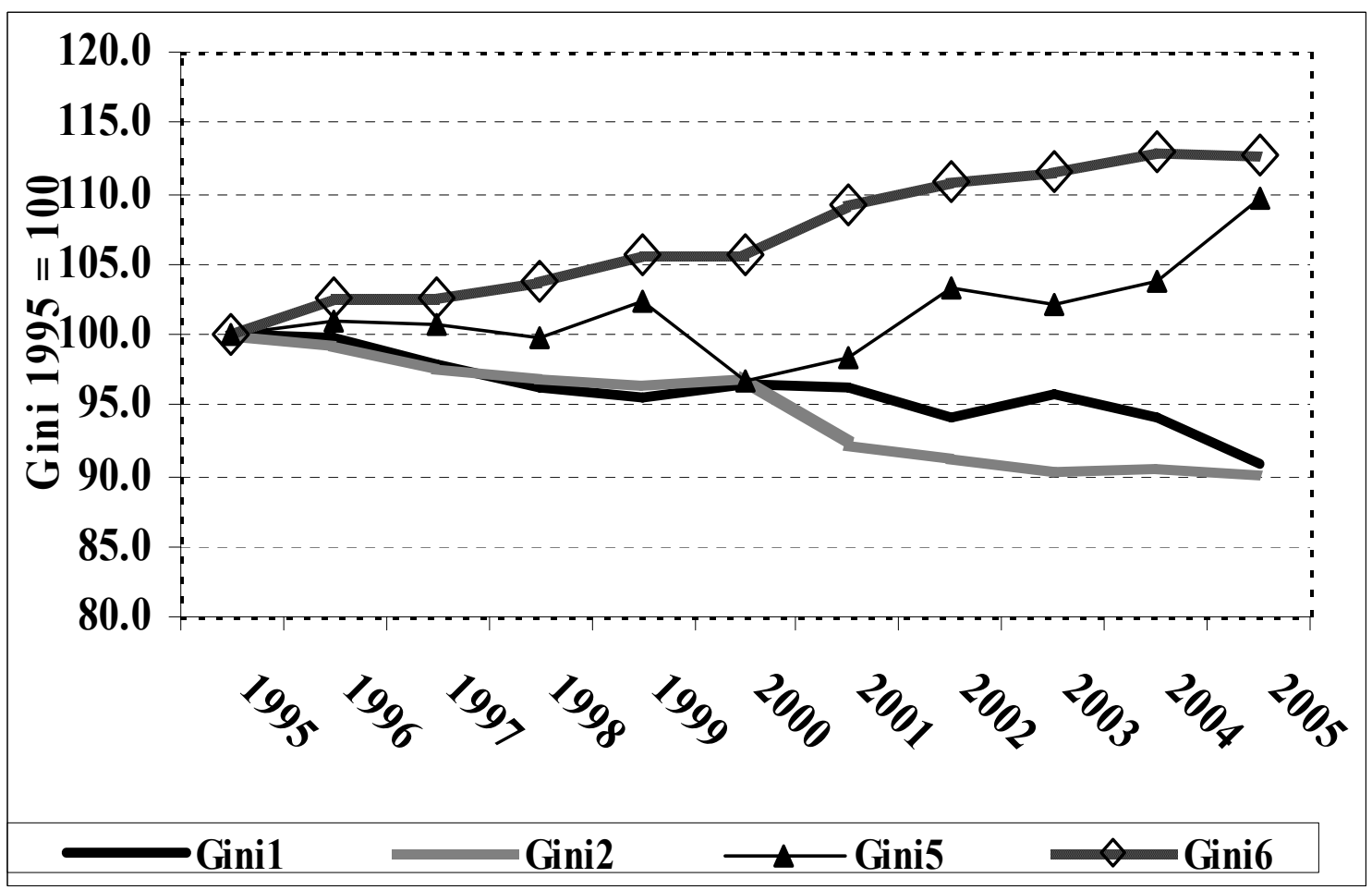

Grafik 11. Gini 1, 2, 5 ve 6 Katsayılarının $1995=100$ Endeksine Göre Karşılaştırmalı Zamansal Gelişimi (1995-2005)

Grafik 11 ve Grafik 12 incelendiğinde görüleceği üzere, 11 yıllık dönemde hizmet arzında bölgesel dağılım eşitsizliğinin iyileştirilmesinde, hizmet talebine göre daha istikrarlı bir iyileşmenin varlığıyla karşılaşılmaktadır. Ancak söz konusu iyileşme, il nüfusları dikkate alındığında bozulmaktadır.

Grafik 12'de dikkat edildiğinde, son üç ve hatta beş yılda hem kütüphane hem de kitap sayısının bölgesel dağılım eşitsizliğinde yaşanan iyileşme hızının düşmüş olduğu görülmektedir. Nüfusa göre düzeltmelerde ise hafif de olsa bir bozulmayla karşılaşılmaktadır. Bu durum, önümüzdeki yıllar için bozulma ya da en azından iyileşmenin çok düşük düzeyde gerçekleşmesi tehlikesine işaret etmektedir. Sosyal politika uygulayıcısı kamusal erk sahiplerinin bu konuda dikkatli olması gerekmektedir. 


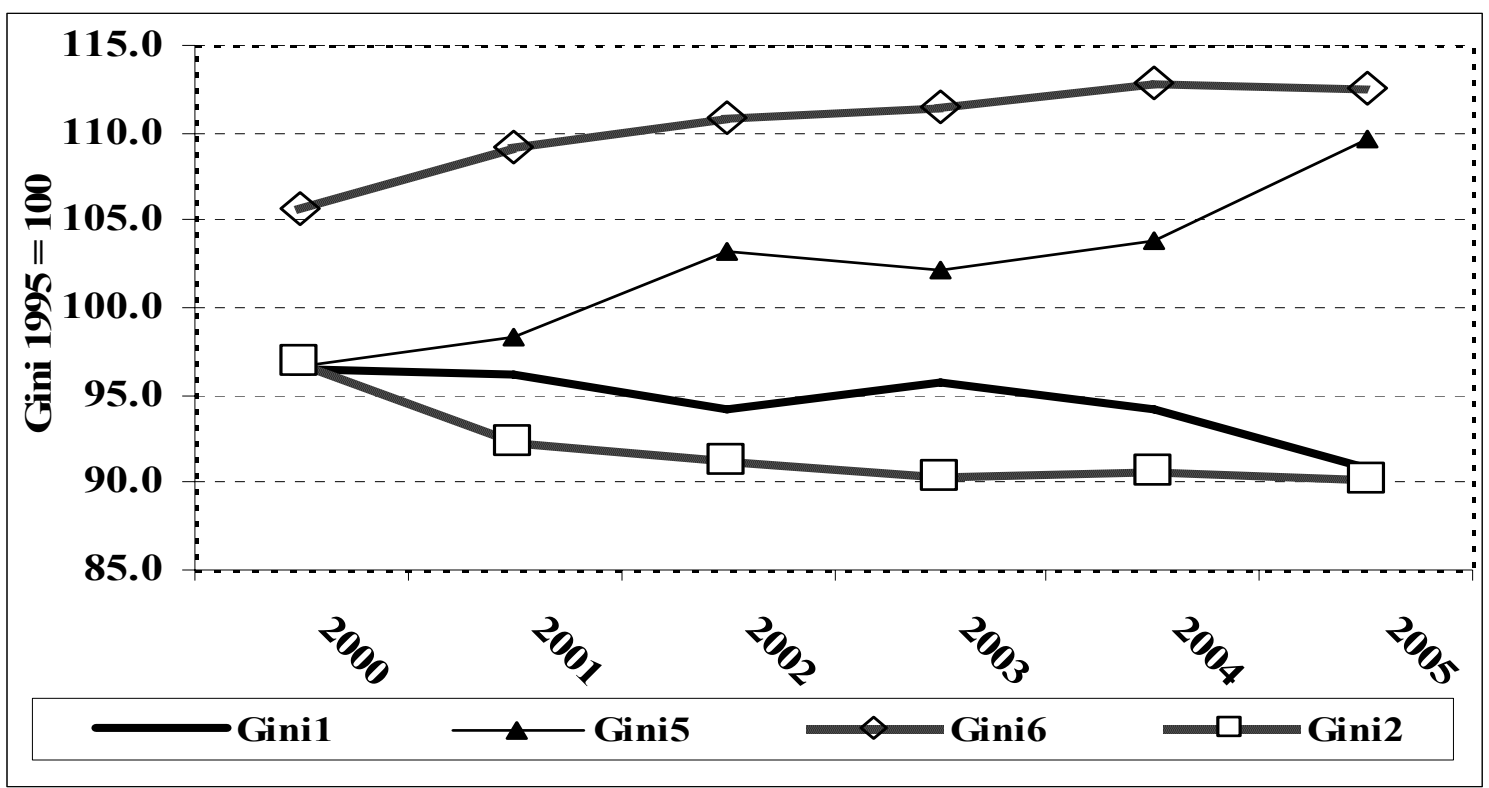

Grafik 12. Gini 1, 2, 5 ve 6 Katsayılarının 1995=100 Endeksine Göre Karşılaştırmalı Zamansal Gelişimi (2000-05)

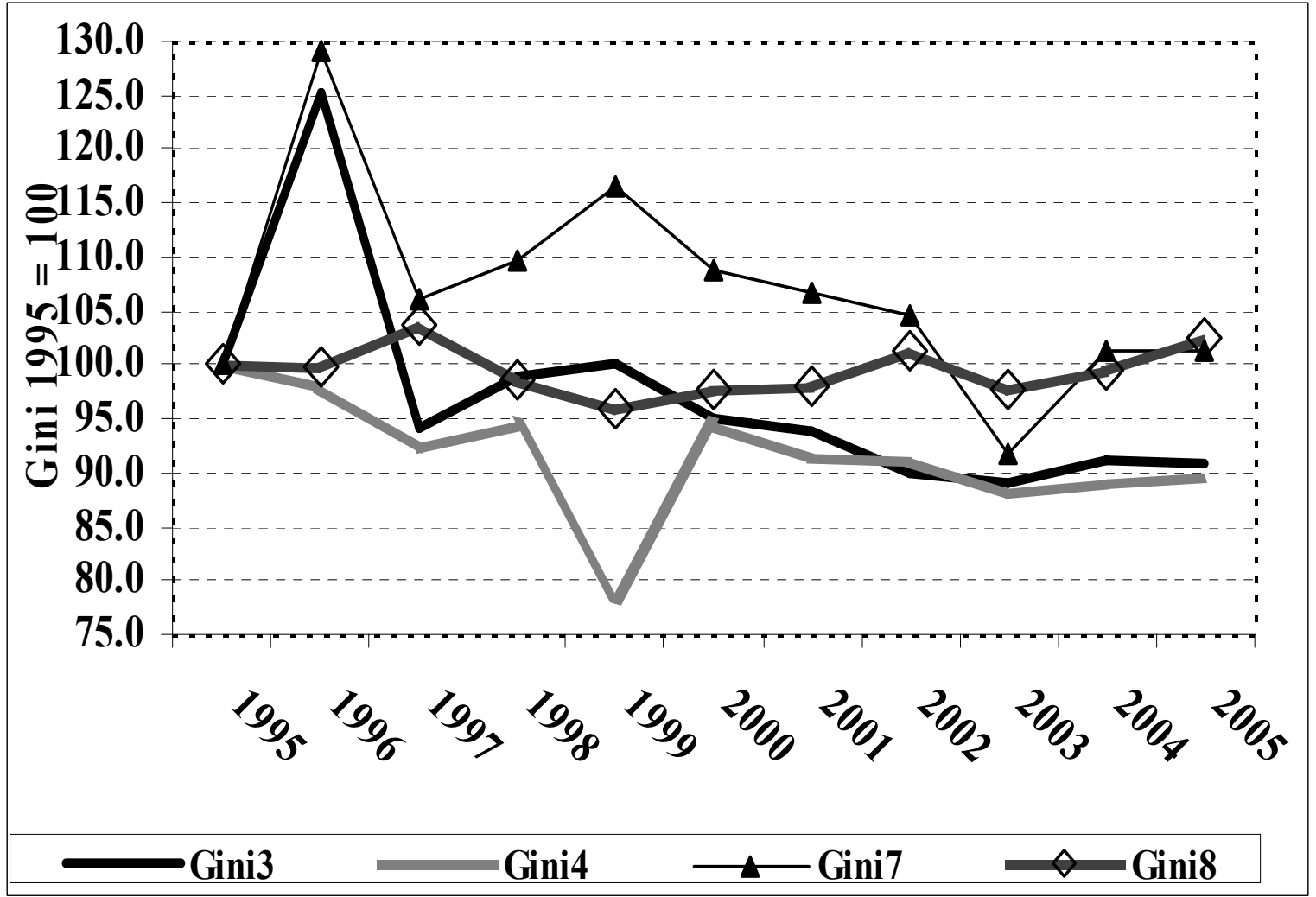

Grafik 13. Gini 3 ,4, 7 ve 8 Katsayılarının 1995=100 Endeksine Göre Karşılaştırmalı Zamansal Gelişimi (1995-2005) 
Grafik 13 ve Grafik 14 incelendiğinde, son zamanlarda özellikle hizmet talebinin bölgesel dağılım eşitliği cephesinde çok tehlikeli bir bozulma eğilimine girildiğinin işaretleri ile karşılaşılmaktadır. Özellikle 2003 yılından sonra hem kullanıcı hem de ödünç kitap sayısında bozulmanın olması; kütüphanelere olan toplumsal talebin yurt sathında yaygın olarak artmadığı, aksine ülkenin önemli bölümünde ciddi bir göreceli daralma ya da duraklamanın yaşandığı anlamına gelmektedir. İl nüfusları dikkate alındığında da benzer eğilim görülmektedir ve bu konuda ciddi önlemler alınmalıdır. Çünkü devlet, siyasal erkine istinaden eksiği olan yerlere yeni kütüphaneler kurabilir, eksik kitapları tamamlayabilir; ancak kimseyi zorla kütüphanelere getiremez. Toplumsal yargı ve tutumları etkilemekse son derece güç ve çaba gerektirici bir dizi karmaşık sosyal politika uygulamalarını gerektirir. Bu sebeple potansiyel tehlikenin biran önce dikkate alınarak önlenmesi son derece önemlidir.

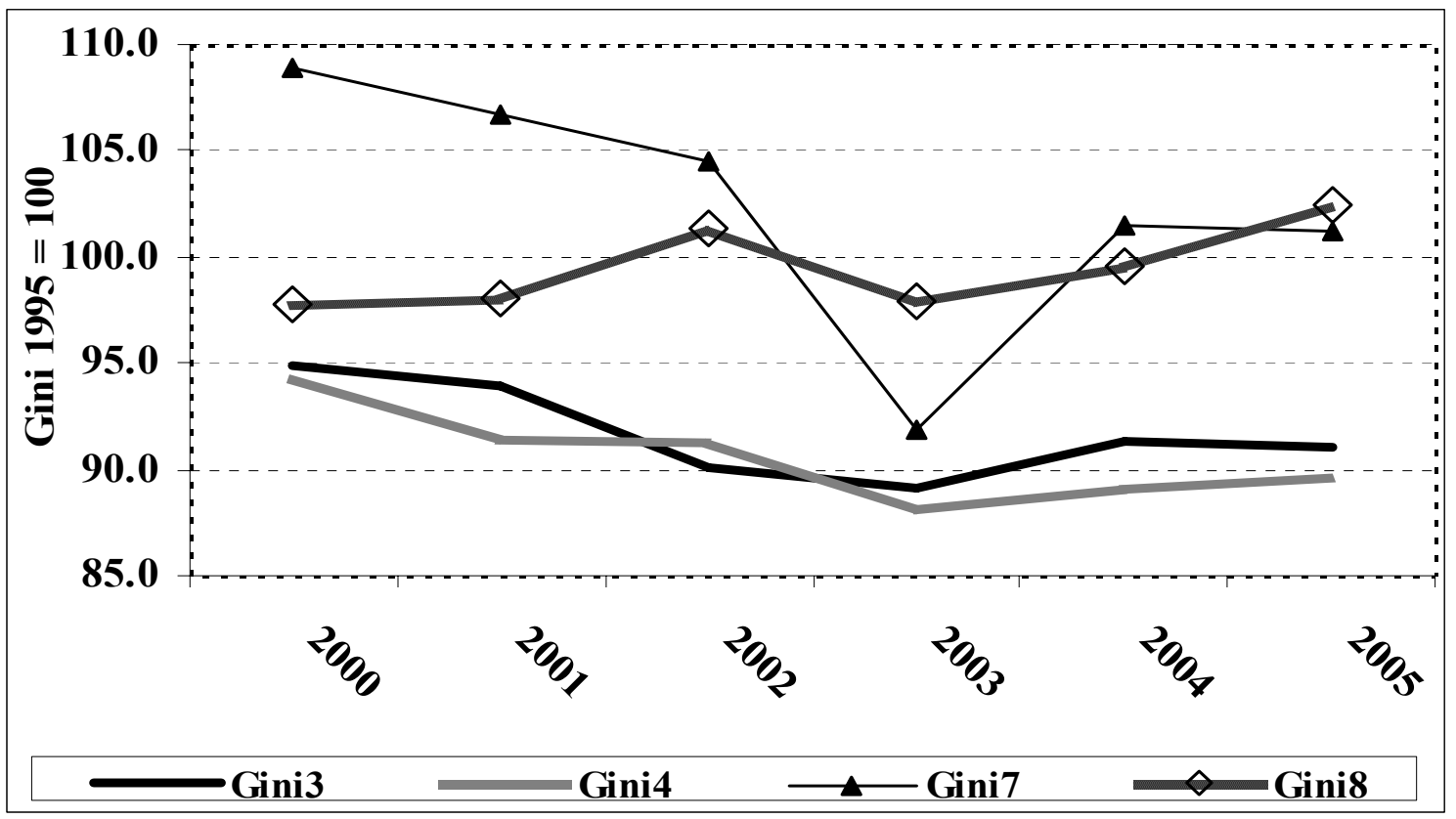

Grafik 14. Gini 3, 4, 7 ve 8 Katsayılarının 1995=100 Endeksine Göre Karşılaştırmalı Zamansal Gelişimi (2000-05)

Bir sonraki aşamada, hizmet arz ve talep göstergelerinin bölgesel dağılım eşitsizliklerinin zamansal gelişimleri arasında istatistiksel bir ilişkinin mevcut olup-olmadığı test edilmiştir. Hipotezi; 
$\left|t_{\text {hes }}\right|>t_{\text {tab }} \Rightarrow x, y$ arasında anlamll bir ilişki var

$\left|t_{\text {hes }}\right|<t_{\text {tab }} \Rightarrow x, y$ arasinda anlamli bir ilişki yok

şeklinde ifade etmek mümkündür. Gözlem sayısının 11 olması durumunda ise $t_{t a b}$ değeri;

$$
\begin{aligned}
& \underset{\substack{n=11 \\
\alpha=0.05}}{\Rightarrow} t_{\text {tab }}=2.262 \\
& \begin{array}{c}
n=11 \\
\alpha=0.10
\end{array} \Rightarrow t_{\text {tab }}=1.833
\end{aligned}
$$

olarak gerçekleşecektir. İstatistiksel açıdan anlamlı bir ilişkinin olması için ise;

$$
\left|t_{h e s}\right|=\left|\frac{r_{x, y} \times \sqrt{n-2}}{1-r_{x, y}^{2}}\right|>t_{t a b}
$$

olması gereklidir. Bu minimum düzeyi sağlayan asgari korelasyon düzeyi ise;

$$
\begin{aligned}
& \alpha=0.05 \Rightarrow\left|t_{\text {hes }}\right|>2.262 \Rightarrow\left|r_{x, y}\right| \geq 0.603 \\
& \alpha=0.10 \Rightarrow\left|t_{\text {hes }}\right|>1.833 \Rightarrow\left|r_{x, y}\right| \geq 0.521
\end{aligned}
$$

olarak tespit edilmiştir. Bu seviyenin altındaki korelasyon düzeyi, değişkenler arasında "Gini katsayıları" anlamlı bir ilişkinin olmadığı

\begin{tabular}{|c|c|c|c|c|c|}
\hline & \multicolumn{4}{|c|}{ Arz gini } \\
\hline & & gini1 & gini2 & gini5 & gini6 \\
\hline \multirow{4}{*}{ Talep gini } & gini3 & ${ }^{\star} 0.63$ & *0.68 & $\ldots$ & $\ldots$ \\
\hline & gini4 & $* * 0.57$ & 0.47 & $\ldots$ & \\
\hline & gini7 & $\ldots$ & $\ldots$ & -0.23 & -0.48 \\
\hline & gini8 & $\ldots$ & $\ldots$ & 0.43 & 0.00 \\
\hline
\end{tabular}
şeklinde yorumlanmalıdır. Tablo 2'de arz ve talep göstergeleri "Gini katsayıları" arasındaki korelasyon değerleri sunulmuştur.

Tablo 2. Arz-Talep Gini Katsayıları Arasında Pearson Korelasyon Değerleri (1995-2005) 
Tablo 2'de görüleceği üzere, hizmet arzının bölgesel dağılım eşitsizliği göstergeleri ile "kütüphane (Gini 1) ve kitap sayıları (Gini 2) için" sadece ziyaretçi sayısının bölgesel dağılım eşitsizliği "Gini 3" arasında pozitif yönlü anlamlı bir istatistiksel ilişki mevcuttur. Ancak hizmet talebinin bölgesel dağılım eşitsizliğinde çok daha önemli gösterge konumundaki ödünç alınan kitap sayısı "Gini 4" için \% 5 hata payında anlamlı bir istatistiksel ilişkinin olmadığı görülmektedir. Hata payı \% 10'a çıkartıldığında ise sadece kütüphane sayısıyla pozitif yönlü anlamlı ilişkinin sağlanabildiği sonucuyla karşılaşılmaktadır. Nüfusa göre yapılan düzeltmelerle hesaplanan Gini değişkenleri arasında ise herhangi bir anlamlı istatistiksel ilişki tespit edilememiştir.

Bir önceki yıla göre yüzdesel değişimler arasında yapılan Pearson korelasyon analizinde, gözlem sayısı on birden ona düştüğünden anlamlı bir istatistiksel ilişkinin varlığını savunmak için korelasyon katsayı değerlerinin alması gereken en düşük değerler;

$$
\begin{aligned}
& \alpha=0.05 \Rightarrow\left|t_{\text {hes }}\right|>2.306 \Rightarrow\left|r_{x, y}\right| \geq 0.632 \\
& \alpha=0.10 \Rightarrow\left|t_{\text {hes }}\right|>1.860 \Rightarrow\left|r_{x, y}\right| \geq 0.551
\end{aligned}
$$

seviyesine yükselmiştir. Buna karşılık Tablo 3'de görüleceği üzere, hizmet arz ve taleplerinin bölgesel dağılım eşitsizliklerindeki yıllık değişim düzeyleri arasında istatistiksel açıdan sadece bin kişiye düşen halk kütüphanelerinin kitap sayısındaki bölgesel eşitsizlik katsayısı ile bin kişi başına düşen halk kütüphanelerinden yararlanan sayısındaki bölgesel eşitsizlik katsayısı arasında \% 10 hata payıyla anlamlı ilişki bulunmuştur. Diğer bir deyişle Gini katsayılarının yıllık dalgalanmaları, neredeyse tamamen birbirlerinden bağımsız gerçekleşmektedir. Bu sonuç, konuyla ilgili sosyal politika uygulamalarının planlı ve arz-talep arasında koordinasyonun sağlandığı bir yapıda gerçekleştirilmesinde sıkıntıların mevcut olduğu yönünde yorumlanabilir. 
Tablo 3. Arz - Talep Gini Katsayılarının Bir Önceki Yıla Göre Yüzde Değişimleri Arasında Pearson Korelasyon Değerleri (1996 - 2005)

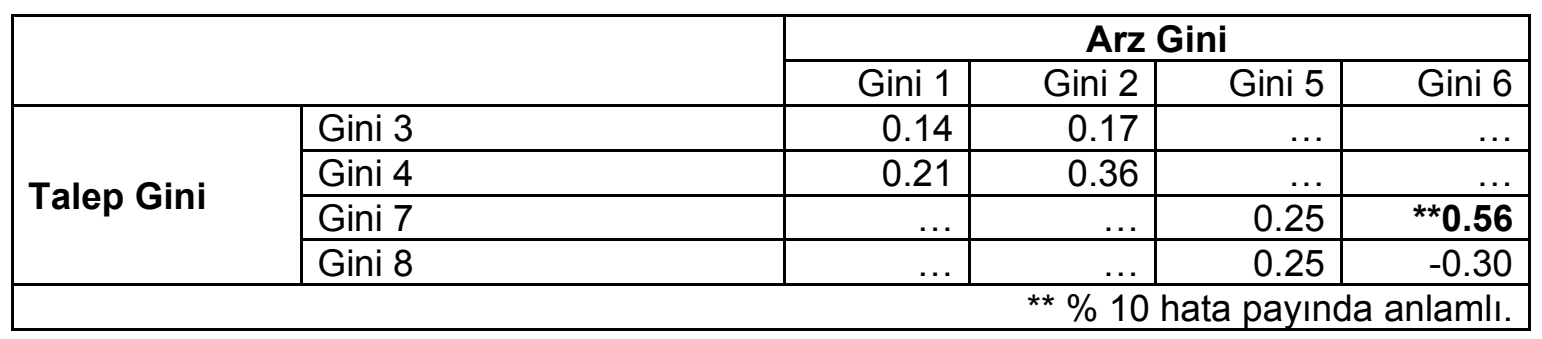

\section{Tartışma ve Sonuç}

Eğitimin her aşaması için okul, kurs ve araştırma merkezleri gibi çok önemli bir enstrüman konumundaki halk kütüphanelerinin iller arasındaki bölgesel dağılım eşitsizliklerini konu alan bu çalışmada özet olarak şu sonuçlara varılmıştır:

Kümülâtif olarak hem arz konumundaki kütüphane ve kitap sayısında, hem de talep konumundaki kullanıcı sayısı ve ödünç alınan kitap sayısında iller itibarıyla bölgesel dağılım eşitsizliğinde 11 yıllık süreç bütünü için bir iyileşmenin varlığıyla karşılaşılmaktadır. Gini 1, 2, 3, 4 katsayılarının gelişimi incelendiğinde 11 yıllık dönem için eşitsizliğin birbirine yakın düzeyde iyileştiği görülmektedir.

İ nüfuslarına göre yapılan düzeltmelerle elde edilen yeni Gini katsayıları (Gini 5, 6, 7, 8) incelendiğinde ise, hem arz konumundaki nüfusa göre ağırlıklandırılmış kütüphane ve kitap sayısında, hem de talep konumundaki nüfusa göre ağırlıklandırılmış kullanıcı sayısı ve ödünç alınan kitap sayısında, iller itibarıyla bölgesel dağılım eşitsizliğinde, 11 yıllık süreç bütününde bir bozulmayla karşılaşılmaktadır.

Bu iki sonuçtan hareketle idarenin, halk kütüphanesi olmayan ya da çok az sayıda mevcudu bulunan illere yeni halk kütüphaneleri kurmak ve bu kütüphanelere sadece bina olarak bakmayıp kitap arzını da sağlayan bir yaklaşım içerisinde olduğunu savunmak mümkündür. İlk bakışta idarenin son derece başarılı olduğunu savunmak mümkünse de, il nüfuslarına göre kitap ve kütüphane arzında iller arası eşitsizliğin yaşanması; uygulanan politikaların etkinliğinin sorgulanmasını gerektirmektedir. Çünkü nüfusu az olan bir ilde, sırf halk kütüphanesi yok ya da 1-2 tane diye yeni 
kütüphaneleri kurmak rasyonel bir bakışın ürünü olmamalıdır. Örneğin nüfusu 2005'te 11 milyonu aşan İstanbul'da 1995'te 62 halk kütüphanesi varken bu sayı 2005'de 37 (Yalova ile birlikte 38)'e, kitap sayısı ise 1.3 milyondan 1.1 milyonun altına indirilirken; 2005 'de nüfusu 80 binin altında olan Tunceli'de 1995 yılında 8 olan halk kütüphanesi sayısının 2005'de 6'ya; kitap sayısının ise 45 binde 57 bine çıkarılması çok da doğru bir yaklaşım olarak değerlendirilmeyebilir. Elbette ülkemizin her köşesi birdir ve iller arasında ayırımcılık yapmak yanlıştır. Ancak bir yandan köklü tarihsel geçmişi olan ve kurumsallaşmasını ileri boyutlara taşıma başarısı göstermiş olan illerimizdeki kütüphaneleri ve kitap mevcudunu alıp nispeten kurumsallaşma sürecini henüz tamamlayamamış olan başka illere kaydırmak da yanlıştır. Bir yeri geliştirmek istenirken gelişmiş yerleri tahrip etmek, yerinde bir davranış değildir.

Talep cephesinden 11 yıllık dönemdeki gelişim incelendiğinde, il nüfuslarının dikkate alınmadığı ilk iki Gini katsayısında (Gini 3, 4) bir düzelme görülmektedir. Bu düzelme iki arz değişkeniyle (Gini 1, 2) yaklaşık olarak aynı düzeydedir. İlk bakışta kullanıcıların ülke genelinde yayıldıklarını düşündüren bu sonuçlar, il nüfuslarına göre ağırlıklandırma yapılması sonrasında elde edilen katsayılarda (Gini $7,8)$ tam tersi bir yapının olduğunu desteklemiştir. Talepteki iller arası dengesizleşmeyi çözmek, arzın dağıtımından çok daha zordur.

Halk kütüphanelerinden ülke toplamı olarak faydalanan "kullanıcı" sayısı 1995'de 2,35 milyon kişiyken bu sayı 2005'e gelindiğinde 2,07 milyona düşmüştür. Buna paralel olarak ödünç alınan kitap sayısında 4,5 milyondan 4,4 milyona inildiği sonucuyla karşılaşılmaktadır. Bu iki gelişmeye dört Gini katsayısının (Gini 3, 4, $7,8) 11$ yıllık gelişimi eklendiğinde, özellikle nüfusu çok olan büyük kentlerde kullanıcıların kütüphanelerden uzaklaştıkları, buna karşılık az nüfuslu küçük kentlerdeki kullanıcı hacminde artış sağlandığı sonucuna varılacaktır. Çünkü il nüfusları göz ardı edildiğinde iller arası kütüphane ve kitap dağılımı eşitleşmekte; il nüfusları dikkate alındığında ise bozulmaktadır. Özetlemek gerekirse büyük kentlerden kullanıcılar kaybedilirken küçük kentlerde yeni kullanıcılar kazanılmaktadır. Kullanıcılarda ülke toplamında yaşanan şiddetli düşüş düşünüldüğünde, büyük kentlerden küçük kentlere 
doğru kütüphane ve kitap arzlarının kaydırılmasının doğruluğu büyük ölçüde tartışmalı hale gelmektedir.

Çalışma kapsamında elde edilen bir başka önemli sonuçsa, Grafik 9 ve Grafik 10'da sunulan yıllık değişimlerdir. Sekiz katsayı arasında genel olarak uyumun bulunmadığı ve birbirinden büyük ölçüde bağımsız hareket eden bir gelişimin olduğu görülmektedir. Bu istikrarsız yıllık hareket, uygulanan politikalar "arz" ve sonuçları "talep" arasında eş zamanlı bir bütünlüğün oluşamadığını desteklemektedir. Nitekim Tablo 2 ve Tablo 3'de sunulan korelasyon katsayı sonuçları da bu uyumsuzluğu yansıtmaktadır. Özellikle nüfusa göre yapılan düzeltmeler sonrasında elde edilen arz ve talep değişkenleri arasında sadece Gini 6 ve Gini 7'deki yıllık değişmeler arasında \%10'luk -çoğu yerde bu düzey istatistiksel anlamlılıkta kabul edilmez- hata payında bir korelasyonun tespit edilebilmesi, bu uyumsuzluğu netleştirmektedir.

Özetle, unutulmamalıdır ki eşitlikçi kalkınma için sosyal politikanın faaliyet konusu sadece intiyaç olan yerlere gerekli hizmeti götürmekle sınırlı olmayıp, toplumun bu alanlara çekimini sağlamayı da içermektedir. Ancak bu şekilde demografik bağlamda ülke bütününde daha eğitimli ve üretken kitlelerin ağırlıkları artırılabilir ve bölgeler arası dağılımdaki eşitsizlik sorunu iyileştirilerek kalkınma teşvik edilebilir. Halk kütüphanelerine tüm ülkeyi kapsayan genişlikteki destek, karar alma mekanizmasındaki erke sahip kişi ve kurumlarca artırılarak sürdürülürken, mevcut arzı iller arasında yeniden dağıtmak yerine arzı genişletmek tercih edilmelidir. Son tahlilde ülkemizin en zengin olduğu "belki de bel bağlanabilecek tek" doğal kaynağı, eğitimli ve üretken - genç insan gücüdür.

\section{Kaynakça}

Alcantara, V. ve Duro, J. A. (2004) Inequality of energy intensities across OECD countries: A note. Energy Policy, 32, 1257-1260.

Gezici, F. (2007). Türkiye'nin bölgelerarası gelişmişlik farkları ve bölgesel politikalarının yeni yaklaşımlar çerçevesinde değerlendirilmesi. Bölge Biliminde Yeni Yaklaşımlar - Bildiriler Kitabı. 12. Ulusal Bölge Bilimi / Bölge Planlama Kongresi içinde (ss. 269-278). İstanbul: Bölge Bilim Türk Milli Komitesi, ITÜ, DPT. 
Hwang, J. (2005). Asset distribution and tertiary education expenditure in developing countries. Economics of Education Review, 24, 171-178.

Laporte, A. (2002). A note on the use of a single inequality index in testing the effect of income distribution on mortality. Social Science \& Medicine, 55, 1561-1570.

Lerman, D. L. ve Lerman, R. I. (1986). Imputed income from owneroccupied housing and income inequality. Urban Studies, 23, 323331.

Milanovic, B. (1997). A simple way to calculate the gin coefficient, and some implications. Economic Letters, 56, 45- 49.

Millimet, D. M. ve Slottje, D. (2002). Environmental compliance costs and the distribution of emissions in the U.S. Journal of Regional Science, 42(1), 87-105.

Mukhopadhaya, P. (2001). Changing labor - Force gender composition and male - female income diversity in Singapore. Journal of Asian Economics, 12, 547-568.

Öztürk, L. (2005). Bölgelerarası gelir eşitsizliği: İstatistiki bölge birimleri sınıflandırmasına (IBSS) göre eşitsizlik indeksleri ile bir analiz, 1965-2001. Akdeniz Üniversitesi IiBBF Dergisi, 10, 95-111.

Pianegonda, S. ve Iglesias. J. R. (2004). Inequalities of wealth distribution in a conservative economy. Physica A, 342,193-199.

Sen, A. K. (1973). On economic inequality. Oxford: Oxford University Press.

Stirböck, C. (2002). Relative specialization of EU regions: An econometric analysis of sectoral gross fixed capital formation. Germany: Centre for European Economic Research.

Tekin, M. ve Çiftçi, M. (2007). Eğitimin iktisadi kalkınmaya etkisi: tarihi gelişim kritikleri, istatistiksel uygulamalar. İstanbul: İ.Ü. İktisat Fakültesi Ekonometri Bölümü. 